\title{
Evaluation of adenosine deaminase seric activity in the diagnosis of bovine tuberculosis
}

\author{
Márcio Roberto Silva/*, Pedro Moacyr Pinto Coelho Mota**, \\ Ricardo de Miranda Henriques Leite***, Francisco Carlos Faria Lobato, \\ Rômulo Cerqueira Leite, Andrey Pereira Lage/ ${ }^{+}$
}

\begin{abstract}
Núcleo de Pesquisa em Saúde Animal, Departamento de Medicina Veterinária Preventiva, Escola de Veterinária, Universidade Federal de Minas Gerais, Av. Antônio Carlos 6627, 30123-970 Belo Horizonte, MG, Brasil *Embrapa Gado de Leite, Coronel Pacheco, MG, Brasil **Laboratório Nacional Agropecuário/MG, Ministério da Agricultura, Pecuária e Abastecimento, Pedro Leopoldo, MG, Brasil ***Empresa de Pesquisa Agropecuária da Paraíba, João Pessoa, PB, Brasil
\end{abstract}

Determination of seric levels of adenosine deaminase (ADA), an enzyme produced by monocytes/macrophages and lymphocytes, has been used in the diagnosis of human tuberculosis (TB). In the present study, ADA seric activity was evaluated comparatively to the comparative tuberculin test in the diagnosis of bovine tuberculosis. Two hundred fifty-six cattle were classified by origin and by the comparative tuberculin test as TB-positive animals $(n=52$, from herds where the Mycobacterium bovis had previously been isolated), and TB-negative animals $(n=204, T B-$ free herds). The mean ADA seric value from the TB-positive group $(4.45 \pm 2.33 \mathrm{U} / \mathrm{L})$ was significantly lower $(p=$ $0.008)$ than that observed in sera from the TB-negative group $(6.12 \pm 4.47 \mathrm{U} / \mathrm{L})$. When animals from a herd with clinical cases of enzootic bovine leukosis of TB-negative group were withdrawn from analysis, the mean ADA seric values of TB-negative group $(5.12 \pm 3.75 \mathrm{U} / \mathrm{L})$ was not significantly different anymore from that of the TB-positive group $(p=0.28)$. There was no agreement in the diagnosis of bovine TB between comparative tuberculin test and determination of ADA seric values, using two different cutoff points, being $6.12 \mathrm{U} / \mathrm{L}$ and $15.0 \mathrm{U} / \mathrm{L},(\mathrm{kappa}=-0.086$ and kappa $=-0.082$, respectively). In conclusion, the determination of ADA seric activity was not a good auxiliary test for bovine TB, because it was not able to distinguish between TB-positive and TB-negative animals.

Key words: bovine tuberculosis - cattle - diagnosis - adenosine deaminase

Bovine tuberculosis (TB) is an important zoonotic disease in cattle caused by Mycobacterium bovis and is more frequent in developing than developed countries (Cosivi et al. 1998, Mota \& Lobato 1998). Although the disease has been considered under control in many developed countries, its reemergence has been observed during the last couple of years (Collins et al. 1994). In Brazil, the mean prevalence of $M$. bovis infection in cattle was estimated to be $1.3 \%$ in the period of 1989 to 1998 (Brasil 2005). In the state of Minas Gerais, a survey of 22,990 animals from 1586 herds performed in 1999 showed a prevalence of $M$. bovis infection of $5 \%$ of the herds and $0.8 \%$ of the animals (Belchior 2001). Herd prevalence increases to $15 \%$ in herds with higher technological management level (Belchior 2001).

The method recommended by the World Animal Health Organization (OIE) (Palmer 2004) and worldwide accepted for the diagnosis of bovine TB is the tuberculin test (Langenegger et al. 1981, Monaghan et al. 1994, O'Reilly 1995, Palmer 2004). However, because tuberculin testing

Financial support: Sebrae MG, Biokits Indústria e Comércio Ltda., FEP/MVZ Coordenação Preventiva

MR Silva: Capes fellowship; RMH Leite, FCF Lobato, RC Leite, and AP Lage: CNPq fellowships

${ }^{+}$Corresponding author: alage@ vet.ufmg.br

Received 9 January 2006

Accepted 27 April 2006 is not very sensitive, the development of more sensitive and specific diagnostic tools could improve bovine TB control and eradication programs (Harboe 1990, Cousins et al. 1991, L'Herminez 1993, Wood \& Rothel 1994, Collins 1995, Thoen \& Bloom 1995).

The enzyme adenosine deaminase (adenosine amino hidrolase - E.C.3.5.4.4. - ADA) is an enzyme involved in the metabolism of purines (Koehler \& Benz 1962, Ammann \& Fudenberg 1980, Giusti \& Galanti 1984) and is widely distributed in lymphoid tissues (Edwards et al. 1971). ADA acts in the differentiation of lymphoid cells (Barton \& Goldshneider 1979, Bothamley et al. 1995), is secreted in biological fluids during the cellular immune response against intracellular pathogens (L'Herminez 1993), but can also be increased in other pathological processes (Chalhoub et al. 1996). The genetic deficiency of ADA production leads to a syndrome characterized by reduction of T cell population in humans (Clark 1995).

In human patients, the determination of ADA activity in several biological fluids is used as an auxiliary diagnostic tool for TB, mainly for extrapulmonary TB (L'Herminez 1993, Pérez-Rodriguez \& Castro 2000, Golden \& Vikram 2005), demonstrating in those clinical forms high sensitivity and specificity (Chalhoub et al. 1996, PérezRodriguez \& Castro 2000, Golden \& Vikram 2005).

Rodrigues et al. (1997) evaluated ADA seric activity in 150 comparative tuberculin test (CTT)-negative animals and 10 CTT-positive animals from the state of Bahia, Brazil and ADA seric activity was significantly higher in diseased cattle. 
The aim of this study was to evaluate the ADA seric activity comparatively to the comparative tuberculin test in the diagnosis of bovine TB in cattle in the state of Minas Gerais.

\section{MATERIALS AND METHODS}

Animals - Two hundred fifty-six adult Holstein-Zebu crossbred cattle from six dairy farms in Minas Gerais, Brazil, were submitted to comparative tuberculin test. Based on their origin and results of the CTT, animals were classified in two groups: (i) a TB-positive group, including 52 CTT-positive animals from three farms where the $M$. bovis had previously been isolated from animals with clinical signs of tuberculosis ( 32 animals from Herd A, 2 from Herd $\mathrm{B}$, and 18 from Herd C), (ii) TB-negative group, including 204 CTT-negative animals from three tuberculosis-free farms (5 animals from Herd D, 104 from Herd E, and 95 from Herd F).

Serum samples - Blood samples were collected through jugular venopunction and sera were prepared and stored at $-20^{\circ} \mathrm{C}$ until tested. The time between blood collection and serum storage was always shorter than $20 \mathrm{~h}$. Only hemolysis-free sera were used because ADA activity from erythrocytes has been shown to increase ADA seric values (Giusti \& Galanti 1984).

CTT - The CTT was performed according to Langenegger et al. (1981) using bovine and avian PPD (Laboratório Regional de Apoio Animal, Ministério da Agricultura, Pecuária e Abastecimento, Pedro Leopoldo, MG, Brazil).

ADA seric activity - ADA seric activity was determined by ADA-Kit (Biokits, Contagem, MG, Brazil), according to the manufacturer, whose methodology is based on Giusti and Galanti (1984), modified by Rodrigues et al. (1993).

Statistical analysis - Mean values of ADA seric activity from TB-positive and TB-negative cattle were compared by Student's t-test after logarithmic transformation $\left[\log _{10}(\mathrm{ADA}+1)\right]$ (Snedecor \& Cochran 1980). Pearson correlation coefficient was computed for data on ADA seric activity and comparative tuberculin test (Snedecor $\&$ Cochran 1980). The frequency and dispersion of ADA seric activity values between TB-positive and TB-negative groups were evaluated graphically. The agreement between ADA seric values and CTT results were evaluated by the kappa statistic (Smith 1995) and Fisher exact test (Snedecor \& Cochran 1980). The statistical analysis were performed by Epi Info (Dean et al. 1995), Minitab (Minitab for Windows, release 9.2, Minitab Inc., US) and WinEpiscope (Frankena et al. 1990) softwares.

\section{RESULTS}

The minimum and maximum ADA seric values (U/L), the mean values and standard deviation from TB-positive and TB-negative animals, as well as the global values for the two groups, are shown in Table I.

The mean ADA seric values for TB-positive animals was significantly lower $(\mathrm{P}=0.008)$ than that observed for TB-negative animals. Also, the highest ADA seric values were found in TB-negative animals from two herds. When animals from Herd E, which had the largest percentage $(16 \%)$ of animals with ADA seric values over $11.22 \mathrm{U} / \mathrm{L}$ (the highest ADA seric values found among TB-positive animals) were withdrawn from analysis, the mean ADA seric values between TB-negative and TB-positive cattle did not differ significantly anymore $(\mathrm{P}=0.28)$.

The dispersion and frequency of ADA seric values between TB-positive and TB-negative groups are shown in Figs 1 and 2, respectively.

To study the agreement between the determination of ADA seric values and the CTT in the diagnosis of bovine TB, two cutoff points were established. One was based

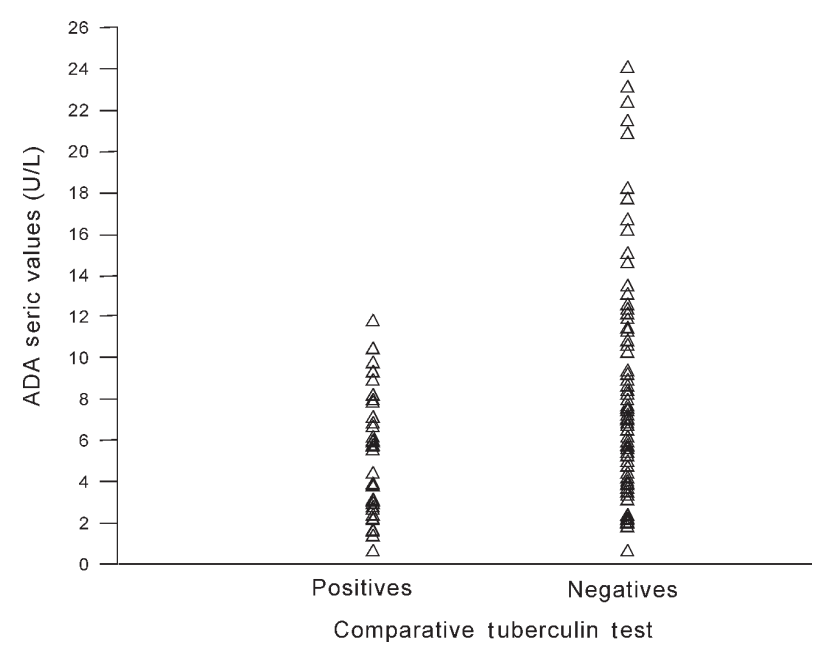

Fig. 1: adenosine deaminase (ADA) seric values (U/L) in sera from animals found positive (52) and negative (204) by the comparative tuberculin test.

\section{TABLE I}

Values of adenosine deaminase (ADA) in sera from tuberculosis (TB)-positive and TB-negative cattle by the comparative tuberculin test

\begin{tabular}{lccc}
\hline & & ADA seric values (U/L) & Maximum \\
\cline { 2 - 4 } Comparative tuberculin test & Mean \pm SD & Minimum & 11.22 \\
\hline Positive $(\mathrm{n}=52)_{\text {Negative }^{a}(\mathrm{n}=204)}$ & $4.45^{c / d} \pm 2.33$ & 0.00 & 23.52 \\
Negative $^{b}(\mathrm{n}=100)$ & $6.12^{c} \pm 4.47$ & 0.00 & 23.52 \\
\hline Total $(\mathrm{n}=256)^{\mathrm{n}=12^{d} \pm 3.75}$ & 0.00 & 23.52
\end{tabular}

$a$ : including animals from Herd $\mathrm{E} ; b$ : excluding animals from Herd $\mathrm{E} ; c: \mathrm{P}=0.008, d: \mathrm{P}=0.28$ 
on the mean ADA seric value of 6.12 U/L from animals of the TB-negative group (Table II) and the other on the mean ADA seric value of $15.00 \mathrm{U} / \mathrm{L}$ observed in ten TBfree animals from the state of Bahia, Brazil (Rodrigues et al. 1997). The kappa values between ADA seric value determination and the CTT were 0.086 and -0.082 using the $6.12 \mathrm{U} / \mathrm{L}$ and the $15.00 \mathrm{U} / \mathrm{L}$ cutoff points, respectively (Tables II, III). The Fisher exact test did not demonstrate any association between ADA seric activity and the CTT $(\mathrm{P}>0.05)$.

The Pearson correlation coefficient between the ADA seric activity and the CTT was low $(r=0.129)$.

\section{DISCUSSION}

The increase of ADA seric activity in biological fluids has been used, with good sensitivity and specificity, as an auxiliary diagnostic tool in human TB, mainly for extrapulmonary TB as in patients with pleural effusions, pericardial effusions, meningitis, and ascitis (L'Herminez
1993, Pérez-Rodriguez \& Castro 2000, Golden \& Vikram 2005), in areas where the prevalence of TB effusions exceeds other effusion causes (Burgess et al. 1995, PérezRodriguez \& Castro 2000, Golden \& Vikram 2005).

The mean seric value of ADA observed among TBnegative animals in the present study was lower than that reported by Rodrigues et al. (1997), but similar to that observed by Yasuda et al. (1996). These differences can be related to the presence of other pathogens or uncontrolled pathologies, as enzootic bovine leukosis, as has been described by Yasuda et al. (1996). Surpringly, the mean ADA seric value observed here was higher in the TB-negative than in the TB-positive group, and this was mainly due to the high frequency (16.34\%) of animals from Herd E that showed ADA seric values over 11.22 U/L, similar to the highest value found among TB-positive animals. When cattle from Herd $\mathrm{E}$ were removed from the statistical analysis, no significant difference was found between the two groups. The high ADA seric values

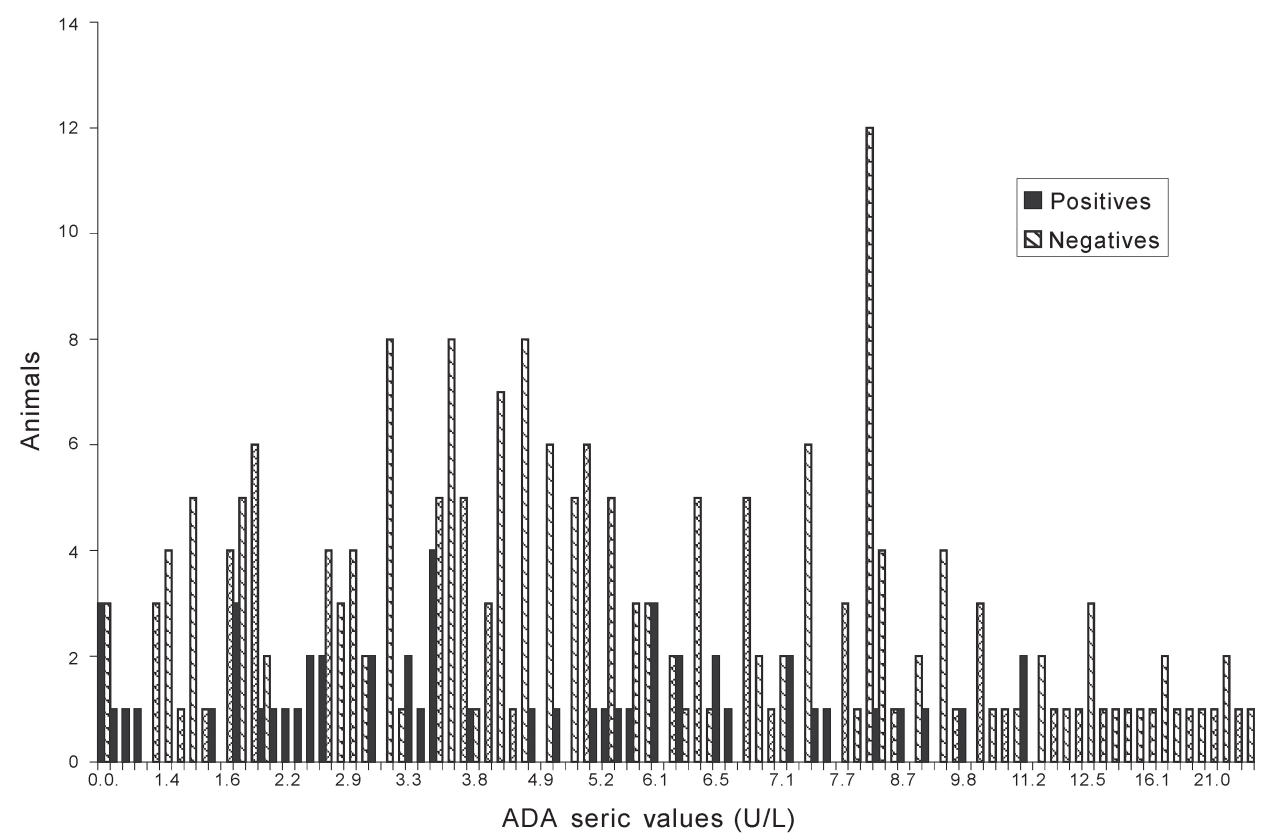

Fig. 2: frequency of adenosine deaminase (ADA) seric values (U/L) from cattle found positive (52) and negative (204) by the comparative tuberculin test.

TABLE II

Agreement of adenosine deaminase seric (sADA) values, with a cutoff of $6.12 \mathrm{U} / \mathrm{L}$, and comparative tuberculin test in the diagnosis of bovine tuberculosis ${ }^{a}$

\begin{tabular}{lccr}
\hline & \multicolumn{2}{c}{ Comparative tuberculin test } & \\
\cline { 2 - 3 } sADA & Positive $^{b}$ & Negative $^{c}$ & Total \\
\hline Positive $^{d}$ & 15 & 82 & 97 \\
Negative $^{e}$ & 37 & 122 & 159 \\
\hline Total & 52 & 204 & 256
\end{tabular}

a: Kappa $=-0.086 ; b$ : animals positive to the comparative tuberculin test, $c$ : animals negative to the comparative tuberculin test; $d$ : animals positive to $\mathrm{ADA}(\geq 6.12 \mathrm{U} / \mathrm{L}) ; e$ : animals negative to $\mathrm{ADA}(<6.12 \mathrm{U} / \mathrm{L}) ; \mathrm{P}>0.05$.
TABLE III

Agreement of adenosine deaminase seric (sADA) values, with a cutoff of $15.00 \mathrm{U} / \mathrm{L}$, and comparative tuberculin test in the diagnosis of bovine tuberculosis ${ }^{a}$

\begin{tabular}{lccr}
\hline & \multicolumn{2}{c}{ Comparative tuberculin test } & \\
\cline { 2 - 3 } sADA & Positive $^{b}$ & Negative $^{c}$ & Total \\
\hline Positive $^{d}$ & 0 & 12 & 12 \\
Negative $^{e}$ & 52 & 192 & 244 \\
\hline Total & 52 & 204 & 256 \\
\hline
\end{tabular}

$a$ : Kappa $=-0.082 ; b$ : animals positive to the comparative tuberculin test; $c$ : animals negative to the comparative tuberculin test; $d$ : animals positive to $\mathrm{ADA}(\geq 15.0 \mathrm{U} / \mathrm{L})$; e: animals negative to $\mathrm{ADA}(<15.0 \mathrm{U} / \mathrm{L}) ; \mathrm{P}>0.05$. 
found in animals from Herd E could be due to infection by agents other $M$. bovis, such as the bovine leukemia virus (BLV). Indeed, clinical signs of enzootic bovine leukosis, confirmed by histopathology, were detected in some animals from Herd E. According to Yasuda et al. (1996), animals with clinical signs of enzootic bovine leukosis have high levels of ADA seric activity.

Although elevated ADA seric levels were reported from human TB patients (Lakshimi et al. 1992, Rodrigues et al. 1993, Orphanidou et al. 1996), measurement of this enzymatic activity had medium to low sensitivity compared to ADA determination in pleural fluid (Lakshmi et al. 1992, Orphanidou et al. 1996). Furthermore, Orphanidou et al. (1996) could not find any correlation between ADA activity in serum and in pleura. In the present study, the lack of a significant difference in ADA seric values between TBpositive and TB-negative cattle could be due to the difference between the production of ADA isoenzymes during immune responses in unlike species to diverse stimulus and to the clinical status of TB-positive animals.

Cattle infected by BLV showed higher ADA seric values when clinical signs of disease were present (Yasuda et al. 1996). In the case of humans infected with M. tuberculosis, ADA seric levels were also higher in patients with positive acid-fast bacilli smear and strong skin test reaction (Lakshimi et al. 1992). Therefore, for human TB, ADA activity is generally employed as an auxiliary diagnostic tool for confirmation of clinical suspicion and correct therapeutic approach (Chalhoub et al. 1996).

The majority of the CTT-positive animals studied here had no clinical signs of TB and this could also partly explain the ADA seric concentration found in this group. Rodrigues et al. (1997) reported ADA seric values higher than $15 \mathrm{U} / \mathrm{L}$ in ten animals with TB but did not describe the clinical status of the animals; more advanced disease in these animals could explain the higher ADA seric values in that study when compared to the present. Even if the determination of ADA seric activity could distinguish animals with signs of TB from the rest of the herd, this would have a restricted use, because just the culling of animals with clinical signs would not eradicate the infection from the herd (Mota \& Lobato 1998).

The comparative tuberculin test, a type IV hypersensitivity reaction, is a cell-mediated response to mycobacterial antigens (Monaghan et al. 1994). Ungerer et al. (1992, 1994) showed that the ADA activity, especially the ADA2 isoenzyme, can also be a useful marker of cell-mediated immunity against $M$. tuberculosis in human TB. Upon regression analysis of ADA seric values and values of skin thickness increasing from CTT, we could not demonstrate an association between these two variables. This suggests that ADA seric activity in cattle does not correspond to a specific cell-mediated response against $M$. bovis, probably because the ADA2 isoenzyme, the major responsible for ADA aticvity in human pleural effusions (Ungerer et al. 1992; 1994), seems to be absent from cattle sera (Tanabe 1993).

The dispersion of ADA seric values between TB-positive and TB-negative cattle in the present study showed a unimodal distribution, i.e., one population curve is in- side the other (Figs 1,2), making it almost impossible to establish a cutoff to separate the two populations and develop an ADA based test with any diagnostic or epidemiologic meaning. In parallel, analysis of ADA seric values and CTT, measured by the kappa statistics, using the two cutoff points showed a complete lack of agreement between the two tests.

The use of ADA seric activity as a diagnostic tool for bovine TB becomes even more unlikely because, similar to what happens in man (Chalhoub et al. 1996), other pathologies such as the clinical presentation of bovine enzootic leukosis could also increase ADA seric activity (Yasuda et al. 1996); the latter disease is widespread in Brazil (Leite et al. 2001).

In conclusion, due to the impossibility of establishing a meaningful cutoff of ADA seric values for separation of TB-positive and TB-negative animals, as compared to the CTT, this test should not be used as an auxiliary test in the diagnosis of bovine TB.

\section{REFERENCES}

Ammann AJ, Fudenberg HH 1980. Enfermidades por inmunodeficiencia. In HH Fudenberg, DP Stites, JL Caldwell, JV Wells (eds), Inmunologia Clínica, 2nd ed., Editorial El Moderno, Mexico.

Barton RW, Goldshneider I 1979. Nucleotide metabolizing enzymes and lymphocytic differentiation. Mol Cell Biochem 28: 135-147.

Belchior APC 2001. Prevalência, Distribuição Regional e Fatores de Risco da Tuberculose Bovina em Minas Gerais, MSc Thesis, Escola de Veterinária da UFMG, Belo Horizonte, 55 pp.

Bothamley GH 1995. Tuberculous pleurisy and adenosine deaminase. Thorax 40: 593-594.

Brasil 2005. Ministério da Agricultura, Pecuária e Abastecimento. Programa Nacional de Controle e Erradicação da Brucelose e da Tuberculose - PNCEBT. www.agricultura.gov.br (access in 4/11/2005).

Burgess LJ, Maritz FJ, Le Roux I, Taljaard JJ 1995. Use of adenosine deaminase as a diagnostic tool for tuberculous pleurisy. Thorax 50: 672-674.

Chalhoub M, Cruz AA, Marcílio C, Netto MB 1996. Valor da determinação da atividade de adenosina desaminase (ADA) no diagnóstico diferencial dos derrames pleurais. Rev Ass Med Brasil 42: 139-146.

Clark WR 1995. At War Within: the Double-Edged Sword of Immunity, Oxford University Press, New York.

Collins DM, Radford AJ, Lisle G, Billman-Jacobe H 1994. Diagnosis and epidemiology of bovine tuberculosis using molecular biological approaches. Vet Microbiol 40: 83-94.

Collins JD 1995. Developments in the diagnosis of tuberculosis. Ir Vet J 48: 149-152.

Cosivi O, Grange JM, Daborn CJ, Raviglione MC, Fujikura T, Cousins D, Robinson RA, Huchzermeyer HF, de Kantor I, Meslin FX 1998. Zoonotic tuberculosis due to Mycobacterium bovis in developing countries. Emerg Infect Dis 4: 5970.

Cousins DV, Wilton SD, Francis BR 1991. Use of DNA ampli- 
fication for the rapid identification of Mycobacterium bovis. Vet Microbiol 27: 187-195.

Dean AG, Dean JA, Coulobier D, Brendel KA, Brendel KA, Smith DC, Burton AH, Dicken RC, Sullivan K, Fagan RF, Amer TG 1995. Epi Info, Version 6: a Word-processing, Database, and Statistics for Public Health on IBM-compatible microcomputers, Centers for Disease Control and Prevention, Atlanta, Georgia, US.

Edwards YH, Hopkinson DA, Harris H 1971. Adenosine deaminase isozymes in human tissues. Ann Hum Genet 35: $207-$ 219.

Frankena K, Noordhuizen JP, Willeberg P, van Voorthuysen PF, Goelema JO 1990. Episcope: computer programs in veterinary epidemiology. Vet Record 126: 573-576.

Giusti G, Galanti B 1984. Colorimetric method. In HU Bergmeyer, Methods of Enzymatic Analysis, 3rd ed., Verlag Chemie, Weinheim, p. 315-323.

Golden MP, Vikram HR 2005. Extrapulmonary tuberculosis: an overview. Am Fam Physician 72: 1761-1768.

Harboe M, Wiker HG, Duncan JR, Garcia MM, Dukes TW, Brooks BW, Turcotte C, Nagai S 1990. Protein G-based enzyme-linked immunosorbent assay for anti-MPB70 antibodies in bovine tuberculosis. J Clin Microbiol 28: 913921.

Koehler LH, Benz, EJ 1962. Serum adenosine deaminase: methodology and clinical applications. Clin Chem 8: 133-140.

L'Herminez RH 1993. Urgent need for a new approach tool the diagnosis of tuberculosis in developing countries in the decade of AIDS. Trop Geograp Med 45: 145-149.

Lakshmi V, Rao RR, Joshi N, Rao PN 1992. Serum adenosine deaminase activity in bacillary or paucibacillary pulmonary tuberculosis. Indian J Pathol Microbiol 35: 48-52.

Langenegger J, Langenegger CH, Mota PMC, Leite RC 1981. Reações inespecíficas no diagnóstico alérgico da tuberculose bovina. Pesq Vet Bras 4: 145-149.

Leite RC, Lobato ZIP, Camargos MF 2001. Leucose enzoótica bovina. Rev CFMV 24: 20-28.

Monaghan ML, Doherty ML, Collins JD, Kazda JF, Quinn PJ 1994. The tuberculin test. Vet Microbiol 40: 111-124.

Mota PMP, Lobato FCF 1998. Tuberculose bovina: uma revisão. In AP Lage, FCF Lobato, PMPC Mota, VSP Gonçalves (eds), Atualização em Tuberculose Bovina, Fundação de Estudo e Pesquisa em Medicina Veterinária e Zootecnia, Coordenação Preventiva, Belo Horizonte, p. 3-34.

O'Reilly LM 1995. Tuberculin skin tests: sensitivity and specificity. In CO Thoen, JH Steele (eds), Mycobacterium bovis
Infections and Animals and Humans, Iowa State University Press, Ames, p. 85-92.

Orphanidou D, Gaga M, Rasidakis A, Dimakou K, Toumbis M, Latsi P, Pandalos J, Christacopoulou J, Jordanoglou J 1996. Tumour necrosis factor, interleukin-1 and adenosine deaminase in tuberculous pleural effusion. Respir Med 90: 95-98.

Palmer NMA 2004. Bovine tuberculosis. In Office International des Epizooties. Manual of Standards for Diagnostic Tests and Vaccines, 5 ed., Office International des Epizooties, Paris 2004. http://www.oie.int/eng/normes/ mmanual/A_00054.htm

Pérez-Rodriguez E, Castro DJ 2000. The use of adenosine deaminase and adenosine deaminase isoenzymes in the diagnosis of tuberculous pleuritis. Curr Opin Pulm Med 6: 259-266.

Rodrigues LEA, Lyra EDEP, Melo MCA 1997. Atividade da adenosina deaminase nos diversos líquidos biológicos como método auxiliar de diagnóstico prático, rápido e barato da tuberculose bovina. Hora Vet 97: 58-61.

Rodrigues LEA, Matias CMC, Araujo FLV, Avila MO 1993. A kit for pratical, simple and rapid assay of adenosine deaminase ativity in biological fluids. Arq Biol Tecnol 36: 115124.

Smith RD 1995. Veterinary Clinical Epidemiology: a Problemoriented Approach, 2nd ed., CRC Press, Boca Raton, 279 pp.

Snedecor GW, Cochran WG 1980. Statistical Methods, 7th ed., Iowa State University Press, Ames, 507 pp.

Tanabe T 1993. Adenosine deaminase activities in the sera and tissues of animals and their clinical significance. Jpn J Vet Res 41: 52 .

Thoen CO, Bloom BR 1995. Pathogenesis of Mycobacterium bovis. In CO Thoen, JH Steele (eds), Mycobacterium bovis Infection in Animals and Humans, Iowa State University, Ames, p. 3-14.

Ungerer JPJ, Oosthuizen HM, Bissbort SH, Vermaak WJ 1992. Serum adenosine deaminase: isoenzymes and diagnostic application. Clin Chem 38: 1322-1326.

Ungerer JPJ, Oosthuizen HM, Retief JH, Bissbort SH 1994. Significance of adenosine deaminase activity and its isoenzymes in tuberculous effusions. Chest 106: 33-37.

Wood PR, Rothel JS 1994. In vitro immunodiagnostic assays for bovine tuberculosis. Vet Microbiol 40: 125-135.

Yasuda J, Tanabe T, Hashimoto A, Too K 1996. Adenosine deaminase (ADA) ativity in tissues and sera from normal and leukaemic cattle. Br Vet J 152: 485-489. 